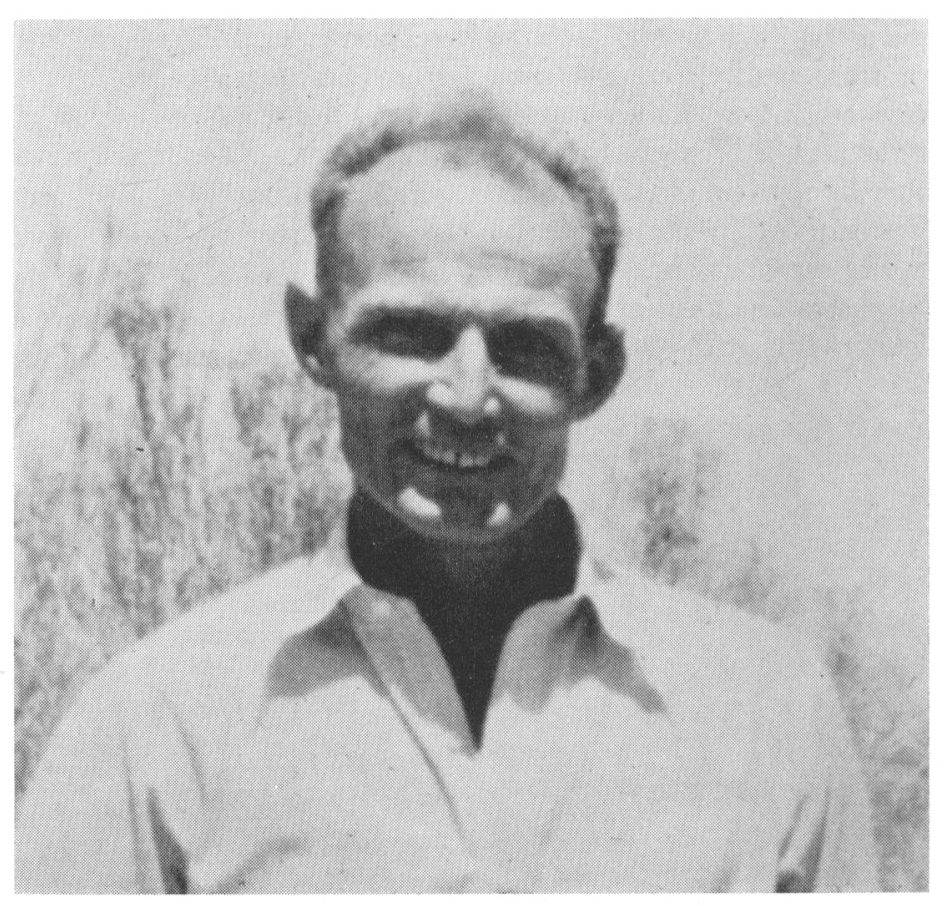

\title{
STANLEY A. STUBBS
}

\section{6-1959}

Most anthropologists can name, among their colleagues, a few whom they esteem much as a fisherman esteems his favorite pool. To a true fisherman, this means more than the catching of fish, although his time-tested conviction that there are fish in his pool - rare, distinguished fish, not to be found elsewhere is an element which draws him to its banks again and again. But what also draws him is a quality of the pool itself - an honesty, perhaps, in the way it meets whatever he brings to it in his fishing. A man can wade such a pool all day, not make a catch, and go home happy.

Stanley Stubbs was like that: a pool of rare knowledge of many things in the American Southwest, but also something more, something in context which gave warmth to fact and stubborn halt to error as he saw them, and which transcended mere discussion of data. At his death - of a heart attack, at his home in Santa Fe on November 22, 1959 - the same tribute was paid him by professionals and amateurs alike, writing from all parts of the country. It was all that any man could wish for: equally to be honored for what he had given, mourned for the loss of what he no longer could give, and remembered with sincere liking and respect for what he was.

Stanley A. Stubbs was born in Albuquerque, June 10, 1906. In 1931, after graduation with a Bachelor of Science degree from the University of New Mexico the previous year, he joined the staff of the new Laboratory of Anthropology, in Santa Fe, as a field archaeologist. He was to remain with the Laboratory for 28 years, the whole of his professional life. 
Dirt archaeology was his first love. He came to know his native state well, from the time of his earliest surveys storing up its geography, geology, and surface evidence of prehistoric occupation in a memory later to be most useful to less peripatetic investigators. In particular, he learned its prehistoric ceramics, and in later years was on continuous call as local or consulting inter-areal judge, in this still incompletely adjudicated field.

He became Curator of the Laboratory in 1938, and upon the institution's merger with the Museum of New Mexico in 1947, he was named Research Associate. In 1950, Sylvanus Morley appointed him Museum Associate in Charge of Anthropology. In a reorganized Division of Anthropology, he became Curator of Collections in 1959.

With W. S. Stallings, Jr., in 1933, he excavated Pindi Pueblo, near Santa $\mathrm{Fe}$ - a landmark in the definition of many temporal traits of the area. He did pioneer work in the Gobernador, and near Alamogordo and in the Sacramentos, and later excavated near Albuquerque, in the Tesuque Valley, at Pecos, and at several historic sites in Santa Fe. Last year he worked two early Spanish mission ruins, at Quarai and Tabira, and at the time of his death was looking forward to more work at Pecos, this summer, to help follow up a lead of Kidder's.

But his interests, and special knowledge, extended far beyond the limits of archaeology. In its early years, the Laboratory was a true clearing-house of studies of Southwestern Indian culture - material, social, and esoteric - and Stubbs was at the center of them all. Every visiting and resident specialist was his tutor, knowingly or not, and he later pursued studies, on his own, which no-one else yet had touched. Word about him spread (fishers are great talkers), and increasingly, to his cluttered desk in the Laboratory, both experts and laymen began bringing their problems on matters ranging from kachinas to kiva patterns, pottery temper to modern turquoise rings, putative bayeta to impossible cord-marked sherds. Always, he gave ungrudgingly of his own time to this work of others, translating it in terms of work to be done, reports to be written, validities to be established - no matter by whom. His own publishing record suffered, in consequence. But the list of articles and major reports by others which acknowledge the use of "information obtained from Stanley A. Stubbs" would fill a goodsized volume.

He leaves his wife, Florence (Crile); a daughter, Mary Lou (Mrs. William J. Ross); and three grandchildren. He also leaves a lasting warmth in the memories of his many friends, the mark of his worth in the records of his profession, and the Southwest's past and present a bit better understood, by everyone, for his having been there and having been the sort of man he was.

\section{Bruce T. Ellis}

1930 Preliminary Report of Excavations near La Luz and Alamogordo, New Mexico. El Palacio, Vol, 29, No. 1, pp. 3-14. Santa Fe.

Survey of Governador Region: Preliminary Report of General Characteristics of the Upper San Juan Area of Rio Arriba County in New Mexico. El Palacio, Vol. 29, No. 2, pp. 75-9. Santa Fe.

1947 New Hall of Ethnology Displays. El Palacio, Vol. 54, No. 12, p. 280 . Santa Fe.

1949 International Congress of Americanists Reviewed. With Edwin N. Ferdon, JR. El Palacio, Vol. 56, No. 292-4. Santa Fe.

1950 Bird's-Eye View of the Pueblos. University of Oklahoma Press, Norman.

1953 The Excavation of Pindi Pueblo, New Mexico. With William S. Stallings, JR. Monographs of the School of American Research, No. 18. Santa Fe.

A Foundation for the Dating of Some Late Ar chaeological Sites in the Rio Grande Area, New Mexico: Based on Studies in Tree-Ring Methods and Pottery Analyses. With T. L. SmlLey and Bryant Bannister, University of Arizona Bulletin, Vol. 24, No. 3, Laboratory of Tree-Ring Research, Bulletin, No. 6. Tucson.

1954 Summary Report on an Early Pueblo Site in the Tesuque Valley, New Mexico. El Palacio, Vol. 61, No. 2, pp. 43-5. Santa Fe.

Museum of New Mexico Archeological Field Work, 1952-1953. Southwestern Lore, Vol. 19, No. 4, pp. 8-9. Boulder.

1955 Archaeological Investigations at the Chapel of San Miguel and the Site of La Castrense, Santa Fe, New Mexico. With Bruce T. Ellis. Monographs of the School of American Research, No. 20. Santa Fe.

1957 "Lost" Pecos Church. With Bruce T. Ellis and Alfred E. Dittert, Jr. El Palacio, Vol. 64, Nos. 3 4, pp. 67-92. Santa Fe.

1959 Prehistoric Woven Asbestos Belt Fragment. El Palacio, Vol. 66, No. 2, inside back cover. Santa Fe. "New" Old Churches Found at Quarai and Tabira (Pueblo Blanco). El Palacio, Vol. 66, No. 5, pp. 1629. Santa Fe. 